\title{
PENDAMPINGAN PEMBELAJARAN MEMILAH DAN MENEMPATKAN SAMPAH PADA TEMPATNYA SEJAK USIA DINI DI TK IMBAS 1
}

\author{
Choirul Amri, ${ }^{*}$, Wahyu Widyantoro² \\ 1,2 Poltekkes Kemenkes Yogyakarta
}

\begin{abstract}
Abstrak
Perubahan perilaku dapat dilakukan melalui kebiasaan yang dipraktikan sejak usia dini. Pembelajaran bagi anak usia dini merupakan tahapan penting untuk pembisaan perilaku. Perilaku hidup sehat dan bersih melalui pengalaman belajar melalui pemberian contoh dan melalukan pembiasaan. Kegiatan ini dilakukan dengan tujuan untuk memperkenalkan dan membiasakan perilaku hidup bersih dan sehat sejak dini melalui pemilahan sampah di TK Imbas 1 (TK ABA Trini) Trihanggo, Gamping, Sleman. Kegiatan ini menggunakan metode demontrasi dan praktik memilah sampah. Diharapkan melalui kegiatan ini anak-anak TK Imbas 1 (TK ABA Trini) mampu mengenal dan mempraktikan memilah sampah pada tempat pemilah sampah.Praktik pemilahan sampah ini dengan pengenalan jenis sampah kepada Murid TK Imbas 1 (TK ABA Trini). Hasil kegiatan ini mampu meningkatkan kebisaan anak-anak dalam menempatkan sampah pada tempat pemilah sampah. Pendekatan perilaku hidup sehat dapat dapat dilakukan sejak usia dini, pengalaman pemilahan sampah sejak dini ini akan memberikan pengalaman perilaku hidup sehat dan bersih sejak dini.
\end{abstract}

\author{
Keywords: \\ PHBS, memilah sampah, \\ usia dini
}

\section{Pendahuluan}

Masalah sampah seakan menjadi persoalan yang terus menyita energi untuk dapat diselesaikan. Berbagai macam sampah sebagai hasil samping kegiatan manusia terus diproduksi setiap harinya. Di pasar, industri, perkantoran, rumah tangga, bahkan di sekolah tidak luput dengan masalah sampah. Hal ini disebabkan oleh kebiasaan masyarakat membuang sampah sembarangan yang sulit dihilangkan. Permasalahan mendasar dari masyarakat dalam membuang sampah sembarangan ini disebabkan karena selama ini masyarakat terlanjur berperilaku atau memiliki kebiasaan yang tidak benar dalam mengelola sampah.

Sekolah sebagai tempat berkumpulnya banyak orang dapat menjadi penghasil sampahterbesar selain pasar, rumah tangga, industri dan perkantoran. Secara umum sampah dapatdipisahkan menjadi : (1) Sampah organik atau mudah busuk berasal dari: sisa makanan, sisa sayuran dan kulit buah-buahan, sisa ikan dan daging, sampah kebun (rumput, daun dan ranting), (2) Sampah anorganik atau tidak mudah busuk berupa : kertas, kayu, kain, kaca, logam,plastik, karet dan tanah.Sampah yang dihasilkan sekolah kebanyakan adalah jenis sampah kering dan hanyasedikit sampah basah. Sampah kering yang dihasilkan kebanyakan berupa kertas, plastik dansedikit logam. Sedangkan sampah basah berasal dari guguran daun pohon, sisa makanan dandaun pisang pembungkus makanan.(Nasih, 2010)

Menurut Peraturan Gubernur Daerah Istimewa Yogyakarta (DIY) nomor 21 tahun 2014, pemilahan sampah merupakan perlakuan awal dalam penanganan sampah dengan memisahkan paling sedikit menjadi tiga jenis sampah, yaitu: (1) Sampah yang mudah terurai, meliputi sampah yang berasal dari tumbuhan, hewan, dan/atau bagian yang dapat terurai oleh makhluk hidup lainnya dan/atau mikroorganisme; (2) Sampah yang dapat digunakan kembali dan sampah yang dapat didaur ulang; dan (3) Sampah yang mengandung bahan berbahaya dan beracun. Sampah yang telah terpilah tersebut harus ditempatkan atau ditampung dalam wadah sampah berdasarkan jenis sampah. (Yogyakarta, 2014)

Pemilahan dan penempatan sampah pada tempatnya merupakan tahapan paling utama yang memungkinkan untuk diterapkan pada usia anak-anak TK sebagai bentuk pembelajaran untuk menanamkan nilai-nilai kebersihan lingkungan sejak dini. Penanaman nilai kebersihan lingkungan terhadap anak sejak dini sangatlah penting, karena anak merupakan generasi penerus bangsa yang 
sebaiknya telah dibekali oleh orang dewasa atau guru mengenai hal-hal yang dapat menjaga keberlangsungan sebuah bangsa dalam hal ini salah satunya adalah dengan menjaga lingkungan bersih. Anak-anak yang masih dalam tahap perkembangan berada pada proses imitasi dengan melihat apa yang orang dewasa di sekitarnya lakukan. (Gunarsa, 2004) Demikian juga dalam hal membuang sampah. Mencontohkan membuang sampah pada tempatnya oleh orang dewasa kepada anak usia dini merupakan salah satu upaya mengurangi kebiasaan buruk yang dapat menyelamatkan lingkungan.

Anak pada usia dini atau seusia anak TK sangatlah mudah untuk diberi pengetahuan atau diarahkan yang lebih baik, dalam hal ini yaitu untuk menjaga kebersihan lingkungan TK. Untuk menjaga kebersihan lingkungan TK ini, anak harus dibiasakan membuang sampah pada tempatnya. Kesadaran anak untuk membuang sampah pada tempatnya menjadi salah satu faktor penting dalam pembelajaran kesehatan lingkungan bersih.

Pengelolaan sampah tidak semata-mata menggunakan teknologi canggih, tetapi lebih membutuhkan perubahan dan pembentukan perilaku individu. Untuk pembentukan perilaku individu dalam mengelola sampah yang benar perlu ditanamkan sejak usia dini, yang merupakan usia emas pembentukan perilaku. Pembentukan perilaku pada usia ini lebih mudah dan lebih terlihat hasilnya daripada usia berikutnya. Pembentukan perilaku mengelola sampah sejak usia dini ini dapat dimulai dari pembentukan kebiasaan memilah dan menempatkan sampah pada tempatnya. Apabila kebiasaan memilah dan menempatkan sampah pada tempatnya sudah tertanam sejak usia dini, selanjutnya diharapkan akan terus terbawa hingga perjalanan usia selanjutnya, yang pada gilirannya akan lebih mudah secara bersama-sama dalam mengelola sampah dan menciptakan lingkungan yang bersih dan sehat.

Pengelolaan sampah di Taman kanak-kanak (TK) Imbas 1 atau TK Aisyiah Bustanul Atfal (ABA) Trini perlu mendapatkan perhatian Anak-anak terlihat masih sering membuang sampah sembarangan. Hanya ada satu bak sampah yang ada, belum disediakan bak sampah dengan tempat sampah terpilah. Setiap hari Sabtu diadakan program perbaikan gizi dengan menu makanan kemasan dos, yang berpotensi menggunung dan bercampurnya berbagai macam sampah pada bak sampah yang ada. Apabila hal ini tidak segera ditangani, anak-anak akan memiliki kebiasaan yang tidak baik. Padahal pada usia mereka merupakan usia emas, yang mana pada usia tersebut mereka mudah menyerap informasi dan mulai tertanamnya nilai-nilai kebiasaan dengan meniru apa yang mereka lihat. Oleh karenanya diperlukan suatu pembelajaran mengenai pengelolaan sampah sejak usia dini. Tahapan pembelajaran pengelolaan sampah yang paling sesuai dengan usia anak TK adalah membuang dan memilah sampah pada tempatnya. Dengan demikian, pembelajaran membuang dan memilah sampah sejak usia dini di TK Imbas 1 (TK ABA Trini) menjadi penting dan mendasar dalam bagian pembentukan perilaku hidup yang bersih dan sehat (PHBS), terutama dari segi kesehatan lingkungan.

\section{Metode/Methods}

Guna mencapai tujuan kegiatan pengabdian masyarakat ini yaitu pembelajaran memilah sampah. Pelaksanaan kegiatan ini dilakukan dengan beberapa metode dan langkah. (1.) Diskusi dengan Guru TK untuk menggali pengelolaan sampah yang telah dilakukan, potensi dan kendala-kendala yang dihadapi dalam pengelolaan sampah, dan menyelaraskan pemahaman kegiatan memilah dan menempatkan sampah pada tempatnya di TK Imbas 1 (2.) Penyediaan bak sampah dengan 3 tempat sampah terpilah, yaitu untuk tempat sampah jenis kertas, plastik, dan daun (sisa makanan).(3.)Memberikan demontrasi memilah dan menempatkan sampah sesuai jenis dan tempat sampah. (4.) Anak-anak TK Imbas 1 melakukan praktik memilah dan menempatkan sampah sesuai jenis dan tempat sampah dengan benar. (5.) Mengevaluasi secara berkala mengenai: (a) kebiasaan anak-anak TK Imbas 1 membuang sampah, dan (b) kebiasaan anak-anak TK Imbas 1 memilah dan menempatkan sampah pada tempatnya.

\section{Hasil Dan Pembahasan}

Pendidikan anak usia dini merupakan upaya pembinaan yang ditujukan kepada anak sejak lahir sampai umur enam tahun, yang dilakukan melalui rangsangan pendidikan untuk membantu pertumbuhan dan perkembangan jasmani dan rohani agar anak memiliki kesiapan belajar dalam memasuki pendidikan lebih lanjut. Terkait dengan hal tersebut, anak-anak usia taman kanak-kanak (TK) sebagai kelanjutan PAUD untuk memberikan pendidikan pra sekolah dalam meletakkan dasar-dasar perkembangan seluruh aspek pendidikan anak. Termasuk aspek pendidikan anak ini yaitu pendidikan pengelolaan sampah. 
TK Imbas I (TK ABA Trini) pada tahun 2016 mengelola dua kelas, yaitu kelas A dan B, dengan jumlah anak didik secara berurutan sebanyak 26 dan 28 anak. Dengan anak didik sejumlah 54 anak ini, pengelolaan sampah cukup menjadi hal yang serius manakala tidak ada pengelolaan yang benar. Namun demikian, pengelolaan sampah ini justeru dapat dijadikan sebagai media pembelajaran bagi anak sejak usia dini mengenai bagaimana cara mengelola sampah yang benar, dimulai dari memilah dan menempatkan sampah pada tempatnya dengan benar. Untuk itulah dilakukan pengabdian kepada masyarakat di TK ABA Trini ini berkaitan dengan menanamkan pendidikan kepada anak sejak usia dini supaya terbiasa memilah dan menempatkan sampah pada tempatnya.

Sebelum dilakukan PKM ini, pengelolaan sampah di TK ABA Trini dilakukan oleh seorang petugas kebersihan. Pada masing-masing kelas telah disediakan satu tempat sampah. Karena hanya satu tempat sampah yang disediakan, sehingga anak-anak belum terbiasa untuk membuang sampah secara terpilah. Kadang-kadang terlihat juga beberapa anak masih belum memiliki kebiasaan membuang sampah pada tempatnya ("membuang sampah sembarangan"). Pada pagi hari petugas kebersihan menyapu halaman TK, sampah dibuang di belakang TK pada tempat yang tidak memadahi, sebagian besar terbuang di lereng pinggir sungai yang berada di belakang TK tersebut, sehinga menimbulkan pemandangan yang kurang mengenakkan di mata. Dengan dilakukannya PKM ini diharapkan juga secara tidak langsung petugas kebersihan terpicu untuk mengelola sampah dengan benar.

Hasil kegiatan dapat dijabarkan sebagai berikut: Pada kegiatan Diskusi dengan guru dilakukan untuk menggali informasi mengenai pengelolaan sampah yang telah dilakukan, potensi dan kendalakendala yang dihadapi dalam pengelolaan sampah, dan menyelaraskan pemahaman kegiatan memilah dan menempatkan sampah pada tempatnya.

Pengelolaan sampah yang telah dilakukan oleh TK Imbas I (TK ABA Trini), antara lain: (1) TK menunjuk 1 orang petugas kebersihan yang bertanggung jawab pada pengelolaan sampah di TK ABA Trini, (2) setiap hari ruangan kelas, ruang Guru, dan halaman dibersihkan, (3) disediakan tempat sampah pada masing-masing ruangan.

Berdasarkan upaya-upaya pengelolaan sampah yang telah dilakukan, TK ABA Trini berpotensi untuk dapat mengelola sampah dengan benar. Guru-Guru TK rata-rata sudah mengetahui pengelolaan sampah. Namun demikian, berdasarkan informasi terdapat beberapa kendala dalam pengelolaan sampah, yaitu: (1) untuk pengelolaan sampah dengan pemilahan sampah terkendala pada belum memiliki tempat sampah terpilah, (2) sulit untuk mengingatkan petugas kebersihan yang terkadang hanya menyapu halaman, tidak membersihkan ruang dalam, (3) tidak cukup dana untuk pengelolaannya.

Dalam diskusi tersebut juga disepakati adanya kegiatan pembelajaran kepada anak-anak TK agar dapat membiasakan diri membuang sampah pada tempat sampah terpilah.

Hasil dari kegiatan Penyediaan bak sampah dengan tiga tempat sampah terpilah adalah tersedianya 2 set tempat sampah, yang masing-masing dengan 3 tempat sampah terpilah sebagaimana disajikan pada Gambar 1, yaitu (1) tempat sampah untuk sampah daun dan sisa makanan, (2) tempat sampah untuk sampah kertas, dan (3) tempat sampah untuk sampah jenis plastik).

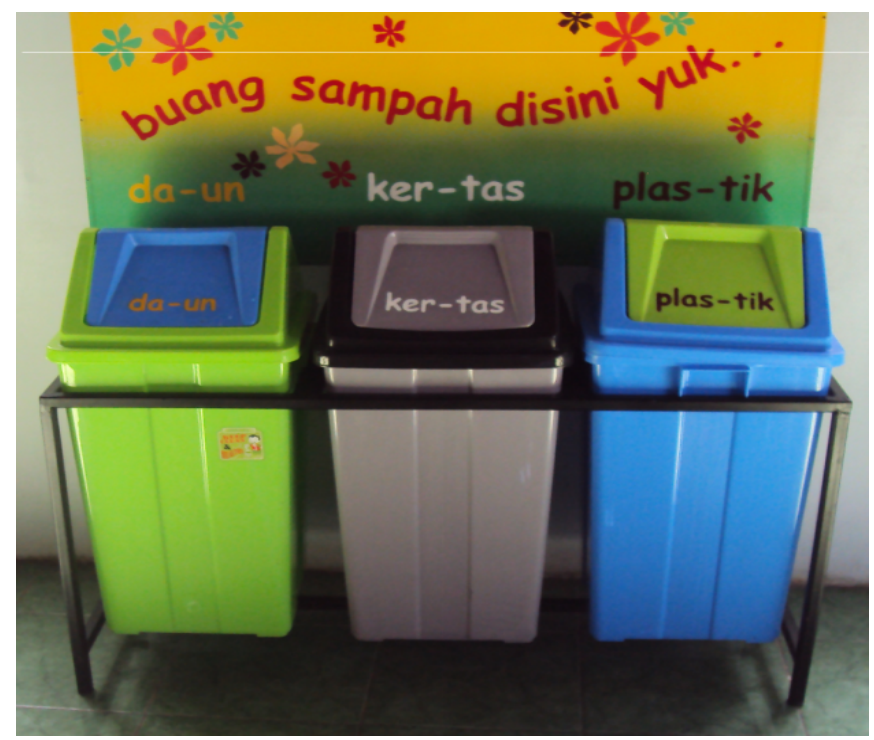

Gambar 1. Satu set tempat sampah dengan 3 tempat sampah terpilah 
Pada kegiatan Demonstrasi memilah dan menempatkan sampah dilakukan demontrasi memilah dan menempatkan sampah sesuai jenis dan tempat sampah. Demontrasi dilakukan oleh Guru TK setelah sebelumnya Guru TK memberikan penjelasan mengenai manfaat membuang sampah dengan benar kepada anak-anak TK.

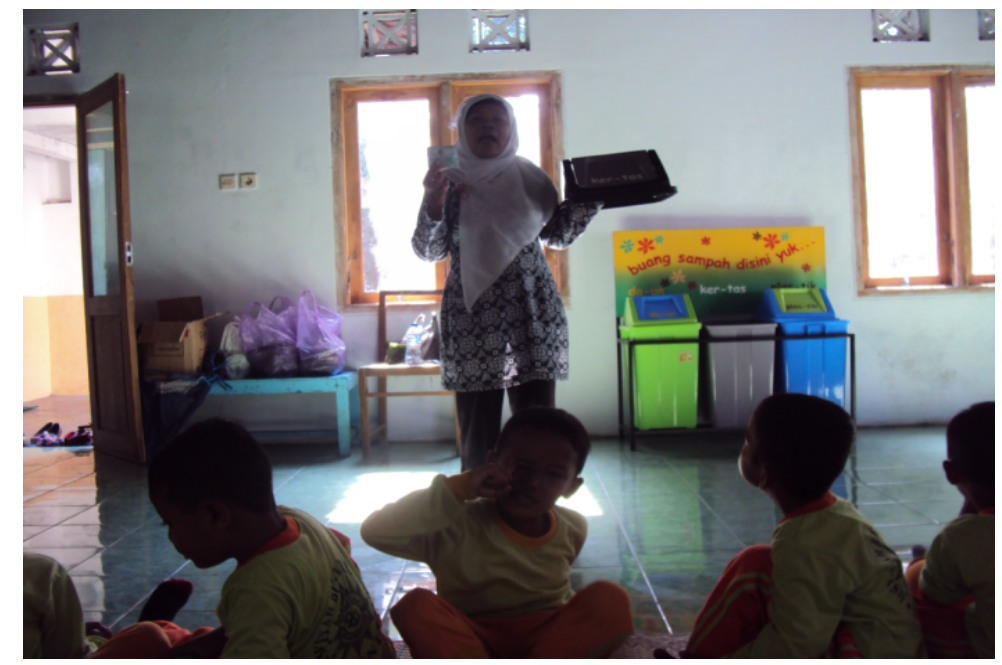

Gambar 2. Guru TK selaku fasilitator menjelaskan membuang sampah pada tempatnya kepada anakanak TK ABA Trini

Setelah anak-anak dijelaskan dan didemontrasikan mengenai cara membuang sampah dengan benar sesuai tempatnya, selanjutnya anak-anak TK mempraktikkan membuang sampah pada tempatnya sesuai dengan jenis sampah. Pada kegiatan ini dibuat skenario dengan diberikan konsumsi kepada anakanak, yang konsumsi tersebut kemasannya ada yang terbuat dari daun, kertas, dan plastik. Setelah selesai makan, anak anak langsung mempraktikkan membuang sampah pada tempat sampah terpilah sesuai dengan tempatnya. Sampah daun dibuang pada tempat sampah daun, sampah jenis kertas dibuang pada tempat sampah kertas, dan sampah jenis plastik dibuang pada tempat sampah plastik. Ketika ada anak yang salah dalam menempatkan/membuang sampah tidak sesuai pada tempatnya, Guru mengingatkan. Kegiatan ini dilakukan dua kali, yaitu pada tanggal 5 Agustus 2016 dan 13 Agustus 2016.

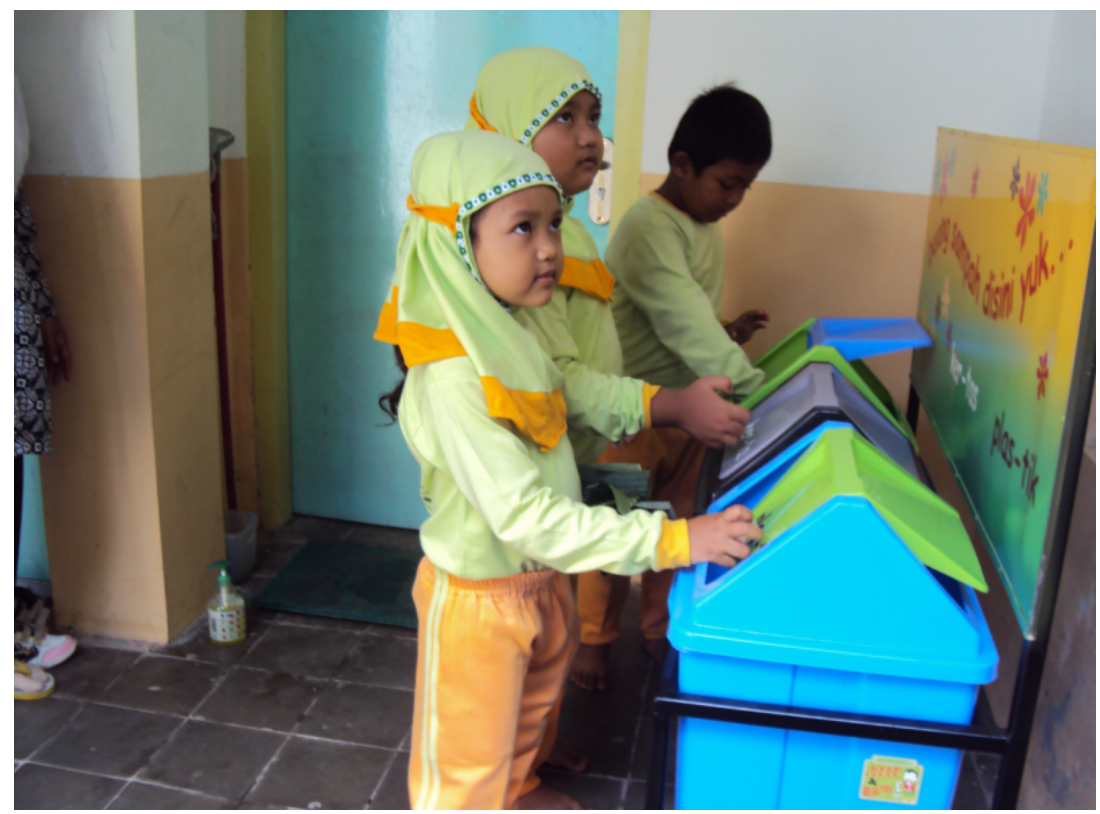

Gambar 3. Anak-anak TK ABA Trini mempraktikkan membuang sampah pada tempatnya sesuai dengan jenis sampah diawasi dan dbimbing oleh Guru. 
Pada kegiatan evaluasi ini dilakukan secara berkala untuk melihat sejauh mana anak-anak TK terbiasa dalam membuang sampahnya pada tempat yang telah disediakan sesuai dengan jenis tempat sampahnya. Setiap hari (hari kerja) selama 1 minggu setelah anak-anak mempraktikkan membuang sampah pada tempatnya dilakukan pengamatan pada tempat sampah mengenai ada tidaknya kekeliruan anak dalam membuang sampah sesuai jenisnya. Pada evaluasi pertama sebagian besar sampah terbuang sudah sesuai tempatnya, namun masih ada beberapa sampah terbuang yang tidak sesuai dengan jenis tempat sampah. Pada evaluasi kedua masih juga ditemukan sampah yang terbuang tidak sesuai pada jenis tempat sampahnya, tetapi hanya 1-2 saja. Secara umum evaluasi kedua sampah terbuang lebih baik (sesuai pada tempatnya) dibandingkan dengan evaluasi pertama.

Kegiatan PKM ini ditujukan untuk menanamkan pada diri anak sejak usia dini mengenai membuang sampah pada tempatnya. Hal ini penting dilakuka mereka (anak-anak TK) merupakan generasi penurus bangsa yang sebaiknya telah dibekali oleh orang dewasa atau guru mengenai hal-hal yang dapat menjaga keberlangsungan sebuah bangsa dalam hal ini salah satunya adalah dengan menjaga lingkungan bersih. Anak-anak yang masih dalam tahap perkembangan proses imitasi dan melihat apa yang orang dewasa di sekitarnya lakukan dalam hal membuang sampah yang tidak pada tempatnya. Mencontohkan membuang sampah pada tempatnya oleh orang dewasa kepada anak usia dini merupakan salah satu upaya mengurangi kebiasaan buruk yang dapat menyelamatkan lingkungan. Perkembangan anak usia TK adalah anak yang sedang mengalami proses imitasi dan bahwa ia sedang memiliki kesadaran moral untuk mencontoh perbuatan yang dilakukan oleh orang dewasa di sekitarnya.

Dengan anak yang seusia dini atau seusia TK sangatlah mudah untuk diberi pengetahuan atau diarahkan yang lebih baik dalam hal ini yaitu untuk menjaga kebersihan lingkungan sekolah. Menjaga kebersihan lingkungan TK ini anak harus membiasakan membuang sampah pada tempatnya, sehingga akan mengurangi efek dari degradasi lingkungan terhadap segala segi kehidupan manusia. Kesadaran anak untuk membuang sampah pada tempatnya menjadi salah satu faktor penting dalam pembelajaran kesehatan lingkungan bersih.

TK ABA Trini memiliki potensi-potensi yang dapat dikembangkan menjadi TK berwawasan lingkungan, yang dengan itu dapat dijadikan sebagai wahana pendidikan anak sejak usia dini mengenai penyelamatan lingkungan, terutama mengenai pengelolaan sampah. Penulis berpendapat, bahwa penanaman pendidikan pengelolaan sampah pada anak usia dini dapat dimulai dari pembelajaran dan pembiasaan anak untuk dapat membuang sampah pada tempatnya. Penempatan tempat sampah juga berpengaruh terhadap perilaku menempatkan sampah pada bak sampah. (Purnomo, Herawati, \& Amri, 2017)

Berdasarkan kegiatan yang dilakukan dalam menanamkan kebiasaan anak dalam membuang sampah pada tempatnya ini secara umum anak dapat mencontoh dengan baik mengenai membuang sampah pada tempatnya sesuai dengan jenis tempat sampahnya. Hasil kegiatan evaluasi menunjukkan evaluasi kegiatan kedua lebih baik dibandingkan dengan evaluasi kegiatan pertama dalam hal ketepatan anak membuang sampah pada tempatnya. Ketika terjadi kekeliruan anak dalam membuang sampah yang tidak sesuai pada tempatnya segera dapat diingatkan dan dibetulkan, dan terus dibiasakan untuk membuang sampah dengan benar, maka dalam diri anak sudah tertanamkan nilai-nilai yang baik dalam memperlakukan sampah.

\section{Kesimpulan}

Berdasarkan hasil kegiatan yang telah dilakukan dapat disimpulkan bebrapa hal diantaranya: 1) Pengelolaan sampah di TK Imbas I (TK ABA Trini) dilakukan oleh seorang petugas kebersihan yang masih dalam batas kebersihan lingkungan, belum berorientasi pada pemanfaatan sampah, sehingga belum ada tempat sampah terpilah, 2) Berdasarkan upaya-upaya pengelolaan sampah yang telah dilakukan, TK ABA Trini berpotensi untuk dapat mengelola sampah dengan benar. Guru-Guru TK rata-rata sudah mengetahui pengelolaan sampah. Namun demikian, terdapat beberapa kendala dalam pengelolaan sampah, yaitu: (1) untuk pengelolaan sampah dengan pemilahan sampah terkendala pada belum memiliki tempat sampah terpilah, (2) sulit untuk mengingatkan petugas kebersihan yang terkadang hanya menyapu halaman, tidak membersihkan ruang dalam, (3) tidak cukup dana untuk pengelolaannya, 3) Pendampingan dan pembelajaran memilah dan menempatkan sampah pada tempatnya di TK Imbas I (TK ABA Trini) berjalan dengan baik. Guru-Guru TK banyak berpartisipasi dalam kegiatan ini, diikuti dengan anak-anak TK yang antusias selama kegiatan, 4) Setelah dilakukan PKM ini, anak-anak TK Imbas I (TK ABA Trini) secara umum telah memiliki kebiasaan membuang sampah pada tempatnya. 


\section{Daftar Pustaka}

Gunarsa, S. . (2004). Psikologi Praktis: Anak, Remaja, dan Keluarga. Jakarta: Gunung Mulia.

Nasih, W. . (2010). Pengelolaan Sampah yang Ramah Lingkungan di Sekolah, Pelatihan Pengembangan Sekolah Hijau untuk guru-guru SMK RSBI se-DIY. LPPM UGM bekerja sama dengan Dinas Pendidikan, Pemuda dan Olah Raga Provinsi DIY.

Purnomo, R., Herawati, L., \& Amri, C. (2017). Penggunaan Tempat Sampah Bermotif Terhadap Perilaku Buang Sampah pada Tempatnya Di Sekolah Dasar Negeri Wilayah Argomulyo, Sedayu, Bantul. Sanitasi: Jurnal Kesehatan Lingkungan, 8(3), 101-105. http://journalsanitasi.keslingjogja.net/index.php/sanitasi/article/view/16/16

Yogyakarta, P. D. . (2014). Peraturan Gubernur Daerah Istimewa Yogyakarta (DIY) nomor 21 tahun 2014, tentang Pedoman Penanganan sampah, perizinan usaha pengelolaan sampah, dan Kompensasi Lingkungan. Pemda DIY. 